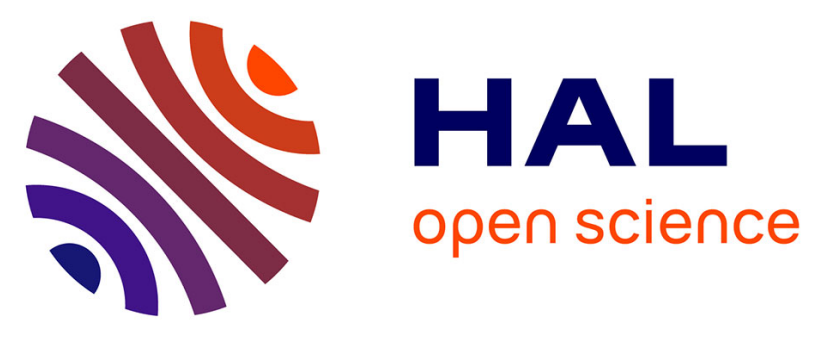

\title{
Resistance induction and herbivore virulence in the interaction between Myzus persicae (Sulzer) and a major aphid resistance gene $(\mathrm{Rm} 2)$ from peach
}

Marie-Hélène Sauge, Jean-Luc Poessel, Thomas T. Guillemaud, Laurent Lapchin

\section{To cite this version:}

Marie-Hélène Sauge, Jean-Luc Poessel, Thomas T. Guillemaud, Laurent Lapchin. Resistance induction and herbivore virulence in the interaction between Myzus persicae (Sulzer) and a major aphid resistance gene (Rm2) from peach. Arthropod-Plant Interactions, 2011, 5 (4), pp.369-377. $10.1007 / \mathrm{s} 11829-011-9141-8$. hal-02649450

\section{HAL Id: hal-02649450 \\ https://hal.inrae.fr/hal-02649450}

Submitted on 29 May 2020

HAL is a multi-disciplinary open access archive for the deposit and dissemination of scientific research documents, whether they are published or not. The documents may come from teaching and research institutions in France or abroad, or from public or private research centers.
L'archive ouverte pluridisciplinaire HAL, est destinée au dépôt et à la diffusion de documents scientifiques de niveau recherche, publiés ou non, émanant des établissements d'enseignement et de recherche français ou étrangers, des laboratoires publics ou privés.

\section{(ㄷ)(1) $\$$}

Distributed under a Creative Commons Attribution - NonCommerciall 4.0 International 
Publié dans / published in: Arthropod-Plant Interactions, 2011

\section{Resistance induction and herbivore virulence in the interaction between Myzus persicae (Sulzer) and a major aphid resistance gene $(\boldsymbol{R m} 2)$ from peach}

Marie-Hélène Sauge • Jean-Luc Poëssel • Thomas Guillemaud • Laurent Lapchin

Marie-Hélène Sauge

Institut National de la Recherche Agronomique, Plantes et Systèmes de culture Horticoles, Site Agroparc, 84914 Avignon Cedex 9, France

Jean-Luc Poëssel

Institut National de la Recherche Agronomique, Génétique et Amélioration des Fruits et Légumes, Domaine Saint Maurice, 84143 Montfavet Cedex, France

Thomas Guillemaud • Laurent Lapchin

Institut National de la Recherche Agronomique, UMR Interactions Biotiques et Santé Végétale, 400 Route des Chappes, 06903 Sophia-Antipolis Cedex, France

Correspondence to: Marie-Hélène Sauge, INRA, Plantes et Systèmes de culture Horticoles, Site Agroparc, F-84914 Avignon cedex 9, France; e-mail: marie-helene.sauge@avignon.inra.fr

Running title: Resistance and virulence in the peach-Myzus persicae interaction 


\begin{abstract}
In gene-for-gene host-enemy interactions, monogenic plant resistance results from pathogen recognition that initiates the induction of plant defense responses. Schematically, as the result of the on/off process of recognition, phenotypic variability in enemy virulence is expected to be qualitative, with either a failure or a success of host colonization. We focussed on a major gene from peach conferring avoidance resistance against the green peach aphid Myzus persicae. Measurements of herbivore density and time-dependent aspects of resistance induction were examined, as well as variability in the aphid's ability to exploit the resistant host. Varying densities of infestation did not provoke differences in the aphid's tendency to leave a plant, and a single aphid was sufficient to elicit a response. Similarly, the duration of infestation did not affect the aphid response. A brief aphid feeding time of $3 \mathrm{~h}$ triggered induced resistance, which became effective between 24 and $48 \mathrm{~h}$ after the initial attack. Induced resistance decayed over time in the absence of additional infestation. Thirty aphid genotypes collected from natural populations were tested in the laboratory. No clone could colonize the resistant host, suggesting that all of them triggered the induction of effective plant defense responses. However, we detected significant quantitative variation among clones in the tendency of aphids to leave plants. These results improve our understanding of induced resistance as a dynamic phenomenon and suggest that the potential for aphids to adapt to a major plant resistance gene may depend on factors other than the mere capacity to evade recognition.
\end{abstract}

Key-words Adaptation • Density dependence $\cdot$ Gene-for-gene plant-insect interactions $•$ Induced resistance $\bullet$ Prunus persica $\bullet$ Timing of induction

\title{
Introduction
}

Models of antagonistic coevolution between host plants and their enemies have been largely based around two major hypotheses. Ehrlich and Raven's (1964) theory was that the evolution of insect specialisation on host plants is constrained by the diversity of the plant secondary metabolites involved in the relationship. In this arms race metaphor, plants accumulate constitutive chemicals, regarded as biochemical defenses if they have negative effects on the herbivores (Wittstock and Gershenzon 
2002). Herbivores have in turn evolved behavioural or biochemical strategies for avoiding plant toxins (Després et al. 2007). Host defense chemicals and herbivore ability to metabolize plant defensive compounds (virulence) across populations may display continuous heritable variation with a high degree of correspondence between host and herbivore phenotypes (Berenbaum and Zangerl 1998).

The gene-for-gene concept proposed by Flor (1955) states that a pathogen is able to infect a host unless the host carries a specific resistance $(R)$ gene that matches a specific pathogen avirulence (Avr) gene. Major $R$ genes act at the earliest stages of pathogen detection by triggering a signaling cascade that culminates in activation of strong defenses. Schematically, pathogens adapt to an $R$ gene because altered or deleted Avr genes allows them to evade recognition (Bent and Mackey 2007). Gene-forgene coevolution, first defined in plant-pathogen associations, was also an inspiration for several interactions between plant and piercing-sucking insects (Kaloshian and Walling 2005; Smith and Boyko 2007). The genetics of the interaction between wheat and the Hessian fly, Mayetiola destructor (Say) (Diptera: Cecidomyiidae), have been generally recognized to fit this model. The interaction is typically manifested as a binary response, i.e. either a resistant plant and dead fly larvae or a susceptible plant and living larvae (Harris et al. 2003). In many interactions between plants and aphids, resistance is controlled by major genes, some of which encode or show tight linkage with plant $R$ proteins conferring resistance to microbial pathogens (Rossi et al. 1998; Klingler et al. 2005; Dogimont et al. 2007). Aphid biotypes that can overcome these forms of resistance have appeared commonly among populations and have been designed on the basis of their qualitative pattern of virulence with respect to these genes (e.g. Alston and Briggs 1977; Porter et al. 1997; Burd et al. 2006).

The distinction between Ehrlich and Raven's hypothesis and the gene-for-gene concept has proven to be useful to understand ecological and evolutionary patterns of variation in resistance and virulence at the population level. In particular, the gene-for-gene concept may help explain the nature of the local adaptation of enemy to host that is difficult to reconcile with the arms race view of coevolution (Kniskern and Rausher 2001). Considering the mode of host-enemy coevolution can also have practical ramifications in agricultural systems, insofar as the type of genetic constraints exerted by resistant crop varieties affects the manner in which herbivorous insects evolve and thus impact 
resistance durability (Gassmann et al. 2009). It was recently demonstrated that the breakdown of monogenic plant resistance occurred less frequently when the $R$ gene was combined to partial resistance quantitative trait loci (Palloix et al. 2009; Brun et al. 2010).

We previously found within the genus Prunus (Rosaceae) genetic variation in induced resistance to the green peach aphid Myzus persicae (Sulzer) (Hemiptera: Aphididae), a polyphagous aphid species, which represents a threat for many crops in the world (Sauge et al. 2006). This genetic system establishes a useful framework for ecological studies of plant-aphid relationships. Moreover, some of these peach [Prunus persica (L.) Batsch] genotypes are used in breeding programmes. This is the case for the cultivar Rubira, which confers strong avoidance resistance causing aphids to leave the plant within a few days (Sauge et al. 2002). The question of resistance durability represents a critical issue in cultivated fruit trees, since the management of resistance genes in time and space remains limited. Thus, we aim to produce information that could help determining to which of the two modes of coevolution the Rubira-M. persicae interaction approximates.

Resistance in Rubira is known to be controlled by a major dominant gene (Pascal et al. 2002). This gene, named $R m 2$, maps at the bottom end of linkage group 1 of an $\mathrm{F}_{2}$ genetic map derived from Rubira and anchored to the "Texas" $\times$ "Earlygold" reference map for Prunus (Lambert and Pascal 2011). During the last decade, much has been discovered about the biochemical interactions that specifically occur during gene-for-gene interactions (Stahl and Bishop 2000; Kaloshian and Walling 2005; Bent and Mackey 2007; Smith and Boyko 2007). By contrast, only a few data are available about Rm2-mediated plant responses to M. persicae infestation (Poëssel et al. 2006). In addition, there are currently no aphid genotypes known to exibit virulence towards $R m 2$, probably because no resistant commercial variety bearing this gene has been released so far. Since intensive screening for virulence has never been performed to date, we do not know if there are variants with preadaptive advantages among natural populations.

Thereupon, our specific objectives were twofold. We first wanted to determine if the induced phenotype of resistance, as measured by the tendency of aphids to leave plants, matches the enemy perception and defense induction processes involved in $R$ gene-mediated resistance. For that, we investigated aphid density and time-dependent aspects of induction. Second, we looked for genetic 
variation in the aphid response to host resistance among natural populations of $M$. persicae and tested the prediction that qualitative differences in the expression of virulence occur among aphid genotypes.

\section{Materials and Methods}

Plants and aphids

Prunus persica cv. Rubira (clone S2605) is a cultivar used as peach rootstock. It was selected in 1980 at the Institut National de la Recherche Agronomique, France, in a red-leaf peach progeny from USA. It is considered to be homozygous at most loci, including the Rm2 locus, and is usually seedpropagated. For all experiments, seedlings were grown in a greenhouse, and surveyed to keep them free of enemies. Plants were tested when six weeks (42 d) old.

Under temperate climate, $M$. persicae host-alternates between the peach where sexual reproduction occurs (primary host) and many herbaceous host plants (secondary hosts). In early spring 2002, thirty aphid colonies were collected in three locations of southern France, in peach orchards planted with susceptible varieties (Table 1) (Guillemaud et al. 2003b). Aphids from each sample were assumed to belong to the clonal progeny of a fundatrix, hatched from sexually-produced eggs. We believed that each colony represented a distinct genotype, an hypothesis that was verified by genotyping a subset of samples using eight microsatellite loci (result not shown). An avirulent laboratory clone (Mp03) used in previous work (Pascal et al. 2002; Sauge et al. 2002, 2006) was added to the set of field clones and used as a reference. We used one parthenogenetic female from each sample to initiate the rearing of 30 new colonies on individual peach seedlings in a growth chamber with a 16 -h day length at $19^{\circ} \mathrm{C}$.

Plant resistance in response to varying densities and timing of aphid infestation

To characterize the induced phenotype of resistance in relation to (i) the intensity and (ii) the timing of aphid feeding stimuli, we carried out four experiments where the two factors were manipulated independently (see Table 2 for experimental designs). We asked several questions. What is the 
threshold density of inducing aphids required to elicit induced resistance, and is the level of induced resistance related to the number of inducing aphids (experiment a)? What is the minimum duration after the beginning of feeding by inducing aphids required to detect induced resistance (experiment $b$ )? Is duration of aphid feeding the same, or can shorter feeding durations trigger induced resistance as well (experiment c)? Finally, what is the time course of induced resistance in the absence of additional aphid feeding (experiment d)?

We conducted the experiments on plants that had been preinfested by M. persicae (clone Mp03) or not (control). Inducing adult aphids were placed on their preferred feeding site (the terminal growing shoot) of each plant of the preinfested group; they were not restricted from dispersing. At the end of the preinfestation period, we removed all aphids. In experiment a, we fixed the duration of preinfestation at 48 hours, a sufficient duration to trigger induced resistance. In experiments b, c, and d, we fixed the number of inducing aphids at 20 to ensure a reasonable aphid density (Sauge et al. 2002). To measure the level of induced resistance, we placed 10 test adult aphids (clone Mp03) on each control and preinfested plant. In the case of preinfested plants, we installed test aphids on the same shoot as the one used for preinfestation. The number of aphids remaining on plants was counted 6 times during the first 48 hours after their installation. The few offspring produced were removed at each inspection. We adopted a short counting period because the longer this period, the higher the probability for an induction by test aphids to occur on control plants. We performed 6 to 10 plant replicates for each treatment.

Genotypic variation in aphid virulence

To determine whether there was variation in the response of $M$. persicae to plant resistance among natural populations and, if so, whether the level of virulence differed qualitatively or quantitatively, we exposed clones collected from several orchards (planted with susceptible peach varieties) to Rubira plants. We placed 25 synchronized adult aphids on each caged plant. Aphids remaining on plants were counted twice a day at 9.00 and 17.00 hours until no more aphids were left. The few offspring produced were not taken into account as a parameter of virulence since they all died on plants before 
completing the final moult. We evaluated the 30 field clones and the reference clone Mp03. We performed two replicates for each clone.

\section{Statistical analysis}

All statistical analyses were performed using the R software (R Development Core Team 2010). Since avoidance resistance can be characterized by the time at which the aphid leaves the plant, we used survival analysis, a statistical method to study time-to-event variables. It is commonly utilized in biomedical research and is also applied in ecological entomology to predicting the foraging behaviour of parasitoids (e.g. Haccou et al. 1991) or modelling population dynamics (Ma and Bechinski 2008). We adopted a Cox's proportional hazards model (Cox 1972) to quantify the plant-leaving tendency of aphids. The model describes the influence of covariates on the instantaneous probability that the aphid leaves the plant, given that it is still on it, according to the equation:

$$
h(t)=h_{0}(t) \exp \beta^{x},
$$

in which $h(t)$ is the plant-leaving tendency (hazard function) after a time $t$ spent on the plant, $h_{0}(t)$ is the baseline hazard at time t (representing the hazard for an individual with the value 0 for all the covariates) and $\beta$ is the regression coefficient of the covariate $x$. If a coefficient $\beta$ is such that the exponential term (the hazard ratio) is greater than one, then the corresponding covariate $x$ has an increasing effect on the plant-leaving tendency. A coefficient $\beta$ leading to a hazard ratio smaller than one reduces this tendency.

We estimated the time taken by an individual aphid to leave the plant as the mean time between the last inspection where it was checked and the first inspection where it was missing. We estimated the coefficient $\beta$ by maximizing a partial likelihood, and we tested the significant effect of the covariates by examining the null hypothesis $\mathrm{H}_{0} \beta=0$ by a likelihood ratio statistics. Covariates in the experiments on host resistance were successively the density and duration of infestation. The baseline hazard was set to the control. Right-censored data were used to take into account aphids remaining on plants after the period of observation had expired, i.e. 48 h. The covariate in the experiment on herbivore virulence was the aphid genotype. The baseline hazard at the mean of all covariates in the 
model was set to the genotype Got 1 . Plant replicates were specified as strata in the model. Strata in a Cox model are regarded as additional sources of variation that must be accounted for the estimation of the coefficients, but whose effects are not considered of particular interest. In a second step we tested for differences in the survival curves of aphids across groups of preinfestation or aphid genotypes using the log-rank test, one of a family of test procedures with parameter $\rho$ defined by Harrington and Fleming (1982).

\section{Results}

Plant resistance in response to aphid infestation

The tendency of $M$. persicae to leave plants of Rubira was affected by preinfestation (Table 3). The amount of damage needed to elicit induced resistance was extremely low. A preinfestation by a single aphid significantly increased the hazard for subsequent individuals to leave the plant, by a factor of $\exp (\beta)=6.31$ on average, that is, by $531 \%$ (Table 3a). Higher numbers of inducing aphids did not lead to an increased level of induced resistance within the tested range (log-rank test: $\chi^{2}=0.5$, d.f. $=3$, $P=0.908$ ), showing that induced resistance was not aphid density-dependent.

Varying timing of preinfestation differentially affected the plant-leaving tendency of aphids. In experiment $\mathrm{b}$ where the aphid behaviour was studied immediately after removing inducing aphids (Table 3b), we found that induced resistance became effective between 24 and $48 \mathrm{~h}$ of aphid feeding, since the minimum duration necessary to detect induced resistance was 48 hours. At this stage, it was not possible to assess if induction required $24 \mathrm{~h}$ or $48 \mathrm{~h}$ of feeding, or some combination. Experiment c indicated that very short feeding times (as short as 3 hours) were sufficient to elicit induced resistance, provided induction was measured 48 hours after the beginning of preinfestation (Table 3c). In addition, when the time since the onset of preinfestation was held constant to 48 hours, there was no significant effect of the duration of preinfestation on the level of plant avoidance (log-rank test: $\chi^{2}=$ 5.1, d.f. $=2, P=0.079)$. 
Induced resistance persisted for at least 48 hours after the end of a 48 hour preinfestation (Table 3d). However, estimated hazard ratios decayed as the time elapsed between the end of preinfestation and the measure of induced resistance increased. The hazard to leave the plant was increased by 317\% when induced resistance was measured immediately after removing the aphids, but only by $241 \%$ and 64\% when induced resistance was measured respectively 24 and 48 hours after the end of the preinfestation. Differences among groups were highly significant (log-rank test: $\chi^{2}=27.8$, d.f. $=2, P<$ $0.0001)$.

Genotypic variation in aphid virulence

No aphid genotype sampled in the orchard could establish colonies on Rubira plants. In addition, when looking at the aphid tendency to leave the plant (Table 4), all the clones had a higher estimated hazard ratio than $\mathrm{Mp03}$, the laboratory reference clone which is known to trigger effective induced resistance (Sauge et al. 2002). Taken together, these results suggest that all clones are avirulent. The fact that Mp03 had the lowest hazard ratio possibly reflects the effects of conditioning (maternal effects), since this laboratory clone was reared continuously on peach without host plant alternation. Excluding these possible conditioning effects would require to rear Mp03 on a secondary host, such as pepper or potato, before to test it on Rubira. Anyhow, since Mp03 has always been maintained on a susceptible peach variety, it is unlikely to have undergone any selective adaptation to Rubira.

Despite the fact that all the field clones were avirulent, we detected highly significant variation among them in plant avoidance (log-rank test: $\chi^{2}=122$, d.f. $=29, P<0.0001$ ). Under identical conditions, the hazard ratio estimated for clone Car 1 was on average four times higher than for clone Car 16 (Table 4). We did not detect any influence of the geographical origin of the genotypes on the estimated aphid plant-leaving tendency (Kruskal-Wallis rank sum test : $\chi^{2}=0.940$, d.f. $=2, P=0.62$ ). 


\section{Discussion}

Data from the first part of this study are not sufficient to prove that the interaction between the gene Rm2 from Rubira and M. persicae follows a gene-for-gene model, but the results are a first step towards accepting such a model. The phenotypic expression of resistance as characterized by the aphid plant-leaving tendency matches the enemy perception and defense induction processes involved in $R$ gene-mediated resistance. A similar behavioural approach was adopted for example in the work by Gómez et al. (2010), where inducible change in leaf palatability measured by means of choice tests with the cabbage army moth, Mamestra brassicae (L.), was interpreted as a sign of defense activation in white clover, Trifolium repens L.. We suggest that induced resistance in Rubira is called an all-ornothing trait, given that its level depends neither on the amount nor on the duration of the aphid feeding stimuli. This qualitative response supports the idea that aphid adaptation might occur because of the loss of pathogen recognition by the plant.

Irrespective of the genetic context of our study, the absence of aphid density-dependence in induction contrats with results from research with arthropods with chewing mouthparts, in which the intensity of herbivory was found to influence the magnitude of induced resistance or defense induction (Agrawal and Karban 2000; Underwood 2000; Massey et al. 2007). This difference may be due to the fact that phloem-feeders do not remove leaf tissue per se. For example Zehnder and Hunter (2007) found that in milkweed (Asclepias) species infested by the oleander aphid, Aphis nerii (Boyer de Fonscolombe) (Hemiptera: Aphididae), aphid density did not lead to increased induction of plant defensive cardenolides.

The speed of responses to enemy attacks may be critical in determining whether the plant or the pest prevails. The time course of $M$. persicae-induced resistance showed a pattern similar to the dynamics of plant defense responses in other well-characterized plant-aphid systems that involve resistance derived from major genes (e.g., Gao et al. 2007; Li et al. 2008). In these systems, plant responses were activated as soon as 6 hours after infestation and extended periods of aphid probing activated more genes, whose number could be finally doubled at 36 or 48 hours after infestation. Then, the induction of defense-related genes declined after 24 or 48 hours. In Rubira, a very brief aphid 
feeding duration is required for producing the defense signal. Then, a short time lag between infestation and defense activation ensures rapid and efficient protection against the aphid, compared to other M. persicae-inducible peach genotypes lacking major resistance gene (Sauge et al. 2006). After peak induction at 48 hours, induced resistance decayed over time in the absence of additional infestation. Determining the possible costs and benefits associated with the activation of defensive traits and maintenance of the induction status for prolonged periods of time deserves investigations, because they may influence the evolution of resistance.

Field data suggest that all M. persicae genotypes tested could be reasonably assigned to a discrete class of avirulence, since no progeny could establish on the plant. It is likely that the matching class of virulence, if it exists, has remained undetected in our sampling scheme because of a low or spatially heterogeneous frequency of virulent genotypes in natural populations. Today, predicting the evolution of resistance conferred by $R m 2$ is difficult. On the one hand, a previous microsatellite analysis exposed a large spatial and temporal genetic variability in French populations of $M$. persicae (Guillemaud et al. 2003a), theoretically necessary to allow adaptive genes to evolve (but see Lombaert et al. 2009). In addition, M. persicae contains considerable genetic variation for host plant adaptation (Weber 1985; Nikolakakis et al. 2003) and insecticide resistance has evolved in the populations from which aphids used in the present work were sampled (Guillemaud et al. 2003b). On the other hand, the selection pressure exerted by $R m 2$ remained very low for more than 30 years, a situation that should not favour the evolution of virulence. In orchards, Rubira is planted as rootstock and thus does not interact with aphid populations. In nursery, it is cultivated as seedling but under strong insecticidal pressure that prevents aphid colonization.

Finally, the important and intriguing finding of this study was the identification of significant quantitative variation in the aphid plant-leaving tendency within the range of avirulent genotypes tested. The conclusion that can be drawn from this result is that virulence in the Rubira-M. persicae interaction may not be qualitative and may also evolve according to the chemical coevolution hypothesis. This assertion seems inconsistent with the interpretation of the first series of experimentations, but it adds weight to the idea that plant-aphid interactions involving genes of the $R$ type may exhibit features consistent with both models of coevolution. There are now at least two cases 
supporting this hypothesis. The gene Mi-1.2 from tomato, Lycopersicon peruvianum (L.) P. Mill., and the gene Vat from melon, Cucumis melo L., are the only two genes of resistance to insects (namely aphids) that have been cloned so far (Rossi et al. 1998; Dogimont et al. 2007). Both belong to the socalled NBS-LRR family of $R$ resistance genes. Hebert et al. (2007) found that Mi-1.2 differentially affected the population growth of distinct isolates of the potato aphid, Macrosiphum euphorbiae (Thomas) (Hemiptera: Aphididae), all of which were classified as avirulent. In melon, Vat confers both resistance to the melon aphid, Aphis gossypii Glover (Hemiptera: Aphididae), and resistance to non-persistent viruses transmission by this same aphid species. Lombaert et al. (2009) detected in aphid populations a continuum of performance response to Vat from complete avirulence to strong virulence, but no variability and no overcoming of Vat resistance were observed for the trait 'virus transmission'. This suggests that A. gossypii is effectively recognized by Vat melon plants, even if the trait 'plant resistance' is overcome.

Large scale analysis of $M$. persicae populations collected from peach genotypes carrying $R m 2$ in experimental orchards is now required to get more information about the formal genetics of the interaction. A detailed characterization of the biochemical interactions that occur in Rubira upon aphid attack is also needed to give evidence for a gene-for-gene interaction. This characterization could also benefit to breeding for durable resistance. Genetic variation in induction of plant metabolites has been reported in several systems (Zangerl and Berenbaum 1990; Agrawal et al. 2002; Stevens and Lindroth 2005). If similar variation exists in plant material derived from Rubira, breeders could select for peach genotypes harbouring the highest concentrations in induced defensive compounds, which might improve the efficiency and durability of resistance.

Acknowledgements We acknowledge J.P. Lacroze for technical assistance, S. Simon for aphid sampling and C. Favret for english correction of an earlier draft. Part of this work received financial supports from the Institut Français de la Biodiversité and Département Santé des Plantes et Environnement, Institut National de la Recherche Agronomique. 
Version préliminaire du manuscrit/ Preliminary version of the manuscript

\section{References}

Agrawal AA, Karban R (2000) Specificity of constitutive and induced resistance: pigment glands influence mites and caterpillars on cotton plants. Entomol Exp Appl 96:39-49. doi:10.1046/j.1570$\underline{7458.2000 .00677 . x}$

Agrawal AA, Conner JK, Johnson MTJ, Wallsgrove R (2002) Ecological genetics of an induced plant defense against herbivores: additive genetic variance and costs of phenotypic plasticity. Evolution 56: 2206-2113. doi:10.1111/j.0014-3820.2002.tb00145.x

Alston FH, Briggs JB (1977) Resistance genes in apple and biotypes of Dysaphis devecta. Ann Appl Biol 87: 75-81

Bent AF, Mackey D (2007) Elicitors, effectors, and the $R$ genes: the new paradigm and a lifetime supply of questions. Annu Rev Phytopathol 45: 399-436. doi:10.1146/annurev.phyto.45.062806.094427

Berenbaum MR, Zangerl AR (1998) Chemical phenotype matching between a plant and its insect herbivore. Proc Natl Acad Sci USA 95: 13743-13748

Brun H, Chèvre AM, Fitt BDL, Powers S, Besnard AL, Ermel M, Huteau V, Marquer B, Eber F, Renard M, Andrivon D (2010) Quantitative resistance increases the durability of qualitative resistance to Leptosphaeria maculans in Brassica napus. New Phytol 185: 285-299. $\underline{\text { doi:10.1146/annurev.phyto.45.062806.094427 }}$

Burd JD, Porter DR, Puterka GJ, Haley SD, Peairs FB (2006) Biotypic variation among North American Russian wheat aphid (Homoptera: Aphididae) populations. J Econ Entomol 99: 18621866

Cox DR (1972) Regression models and life-tables. J Roy Stat Soc B 34: 187-220.

Després L, David JP, Gallet C (2007) The evolutionary ecology of insect resistance to plant chemicals. Trends Ecol Evol 22: 298-307. doi:10.1016/j.tree.2007.02.010

Dogimont C, Bendahmane A, Pitrat M, Burget-Bigeard E, Hagen L, Le Menn A, Pauquet J, Rousselle P, Caboche M, Chovelon V (2007) Gene resistant to Aphis gossypii. United States of America patent no 0070016977

Ehrlich PR, Raven PH (1964) Butterflies and plants: a study in coevolution. Evolution 18: 586-608 
Flor HH (1955) Host-parasite interaction in flax rust - its genetics and other implications.

Phytopathology 45: 680-685

Gao LL, Anderson JP, Klingler JP, Nair RM, Edwards OR, Singh KB (2007) Involvement of the octadecanoid pathway in Bluegreen aphid resistance in Medicago truncatula. Mol Plant Microbe Interact 20: 82-93. doi:10.1094/MPMI-20-0082

Gassmann AJ, Onstad DW, Pittendrigh BR (2009) Evolutionary analysis of herbivorous insects in natural and agricultural environments. Pest Management Sci 65: 1174-1181. doi:10.1002/ps.1844

Gómez S, van Dijk W, Stuefer JF (2009) Timing of induced resistance in a clonal plant network. Plant Biol 12: 512-517.doi:10.1111/j.1438-8677.2009.00234.x

Guillemaud T, Mieuzet L, Simon JC (2003a) Spatial and temporal genetic variability in French populations of the peach-potato aphid, Myzus persicae. Heredity 91: 143-152. doi:10.1038/sj.hdy.6800292

Guillemaud T, Brun A, Anthony N, Sauge MH, Boll R, Delorme R, Fournier D, Lapchin L , Vanlerberghe-Masutti F (2003b) Incidence of insecticide resistance alleles in sexually-reproducing populations of the peach-potato aphid Myzus persicae (Hemiptera: Aphididae) from southern France. Bull Entomol Res 93: 289-297. doi:10.1079/BER2003241

Haccou P, Devlas SJ, Van Alphen JJM, Visser ME (1991) Information-processing by foragers Effects of intra-patch experience on the leaving tendency of Leptopilina heterotoma. J Anim Ecol 60: 93-106

Harrington DP, Fleming TR (1982) A class of rank test procedures for censored survival data. Biometrika 69: 553-566

Harris MO, Stuart JJ Mohan M, Nair S, Lamb RJ, Rohfritsch O (2003) Grasses and gall midges: plant defense and insect adaptation. Annu Rev Entomol 48: 549-577. doi:10.1146/annurev.ento.48.091801.112559

Hebert SL, Jia L, Goggin FL (2007) Quantitative differences in aphid virulence and foliar symptom development on tomato plants carrying the Mi resistance gene. Environ Entomol 36: 458-467

Kaloshian I, Walling LL (2005) Hemipterans as plant pathogens. Annu Rev Phytopathol 43: 491-521. doi:10.1146/annurev.phyto.43.040204.135944 
Klingler J, Creasy R, Gao L, Nair RM, Calix AS, Spafford Jacob H, Edwards OR , Singh KB (2005) Aphid resistance in Medicago truncatula involves antixenosis and phloem-specific, inducible antibiosis, and maps to a single locus flanked by NBS-LRR resistance gene analogs. Plant Physiol 137: 1445-1455. doi:10.1146/annurev.phyto.43.040204.135944

Kniskern J, Rausher MD (2001) Two modes of host-enemy coevolution. Popul Ecol 43: 3-14. doi:10.1111/j.1365-3040.2008.01823.x

Lambert P, Pascal T (2011) Mapping Rm2 gene conferring resistance to the green peach aphid (Myzus persicae Sulzer) in the peach cultivar "Rubira®”. Tree Genet Genomes. doi: 10.1007/s11295-0110394-2

Li Y, Zou J, Li M, Bilgin DD, Vodkin LO, Hartman GL, Clough SJ (2008) Soybean defense responses of the soybean aphid. New Phytol 179: 185-195. doi:10.1111/j.1469-8137.2008.02443.x

Lombaert E, Carletto J, Piotte C, Fauvergue X, Lecoq H, Vanlerberghe-Masutti F, Lapchin L (2009) Response of the melon aphid, Aphis gossypii, to host-plant resistance : evidence for high adaptive potential despite low genetic variability. Entomol Exp Appl 133: 46-56. doi:10.1111/j.15707458.2009.00904.x

Ma Z, Bechinski EJ (2008) A survival-analysis-based simulation model for Russian wheat aphid population dynamics. Ecol Model 216: 323-332. doi:10.1016/j.ecolmodel.2008.04.011

Massey FP, Roland Ennos A, Hartley SE (2007) Herbivore specific induction of silica-based defences. Oecologia 152: 677-683. doi:10.1007/s00442-007-0703-5

Nikolakakis NN, Margaritopoulos JT, Tsitsipis JA (2003) Performance of Myzus persicae (Hemiptera: Aphididae) clones on different host-plants and their host preference. Bull Entomol Res 93: 235-242. doi:10.1079/BER2003230

Palloix A, Ayme V, Moury B (2009) Durability of plant major resistance genes to pathogens depends on the genetic background: experimental evidence and consequences for breeding strategies. New Phytol 183: 190-199. doi:10.1111/j.1469-8137.2009.02827.x

Pascal T, Pfeiffer F, Kervella J, Lacroze JP, Sauge MH (2002) Inheritance of green peach aphid resistance in the peach cultivar 'Rubira'. Plant Breed 121: 459-461. doi:10.1111/j.1439-

0523.2002.tb02053.x

Comment citer ce document and a major aphid resistance gene (Rm2) from peach. Arthropod Plant Interactions, 5 (4), 
Poëssel JL, Sauge MH, Corre MN, Renaud C, Gaudillère M, Maucourt M, Deborde C, Dufour C, Loonis M, Lacroze JP, Pascal T, Moing A (2006) Metabolic profiling of shoot apices infested by the peach-potato aphid in susceptible and resistant peach cultivars. Metabolomics 2: 288

Porter DR, Burd JD, Shufran KA, Webster JA, Teetes GL (1997) Greenbug (Homoptera: Aphididae) biotypes: selected by resistant cultivars or preadapted opportunists? J Econ Entomol 90: 1055-1065

R Development Core Team (2010) R: A Language and Environment for Statistical Computing R Foundation for Statistical Computing, Vienna, Austria Available at http://wwwR-projectorg. Accessed 22 April 2010

Rossi M, Goggin FL, Milligan SB, Kaloshian I, Ullman DE, Williamson VM (1998) The nematode resistance gene Mi of tomato confers resistance against the potato aphid. Proc Natl Acad Sci USA 95: 9750-9754

Sauge MH, Lacroze JP, Poëssel JL, Pascal T, Kervella J (2002) Induced resistance by Myzus persicae in the peach cultivar 'Rubira'. Entomol Exp Appl 102: 29-37. doi:10.1046/j.1570-7458.2002.00922.x

Sauge MH, Mus F, Lacroze JP, Pascal T, Kervella J, Poëssel JL (2006) Genotypic variation in induced resistance and induced susceptibility in the peach-Myzus persicae aphid system. Oikos 113: 305-313 Smith CM, Boyko EV (2007) The molecular bases of plant resistance and defense responses to aphid feeding: current status. Entomol Exp Appl 122: 1-16. doi:10.1111/j.1570-7458.2006.00503.x

Stahl EA, Bishop JG (2000) Plant-pathogen arms race at the molecular level. Curr Opin Plant Biol 3: 299-304. doi:10.1016/S1369-5266(00)00083-2

Stevens MT, Lindroth RL (2005) Induced resistance in the indeterminate growth of aspen (Populus tremuloides). Oecologia 145: 298-306. doi:10.1007/s00442-005-0128-y

Underwood N (2000) Density dependence in induced plant resistance to herbivore damage: threshold, strength and genetic variation. Oikos 89: 295-300. doi:10.1034/j.1600-0706.2000.890210.x

Weber G (1985) Genetic variability in host plant adaptation of the green peach aphid, Myzus persicae. Entomol Exp Appl. 38: 49-56

Wittstock U, Gershenzon J (2002) Constitutive plant toxins and their role in defense against herbivores and pathogens. Curr Opin Plant Biol 5: 300-307. doi:10.1016/S1369-5266(02)00264-9

Zangerl AR, Berenbaum MR (1990) Furanocoumarin induction in wild parsnip - Genetics and 
Version préliminaire du manuscrit/ Preliminary version of the manuscript

populational variation. Ecology 7: 1933-1940

Zehnder CB, Hunter MD (2007) Interspecific variation within the genus Asclepias in response to herbivory by a phloem-feeding insect herbivore. J Chem Ecol 33: 2044-20. doi:10.1007/s10886-007$\underline{9364-4}$ 
Version préliminaire du manuscrit/ Preliminary version of the manuscript

Table 1 Geographical origin and number $(n)$ of Myzus persicae genotypes collected from peach orchards in southern France. The distance between the sampled orchards is given in Guillemaud et al. (2003a)

\begin{tabular}{llcccl}
\hline Location & Date & $n$ & Longitude & Latitude & Genotype label \\
\hline Gotheron & 25 February 2002 & 8 & $4^{\circ} 57^{\prime} \mathrm{E}$ & $44^{\circ} 58^{\prime} \mathrm{N}$ & Got 1-8 \\
Carros & 27-28 March 2002 & 16 & $7^{\circ} 11^{\prime} \mathrm{E}$ & $43^{\circ} 47^{\prime} \mathrm{N}$ & Car 1-16 \\
Avignon & 2 April 2002 & 6 & $4^{\circ} 48^{\prime} \mathrm{E}$ & $43^{\circ} 56^{\prime} \mathrm{N}$ & Avi 1-6 \\
\hline
\end{tabular}


Version préliminaire du manuscrit/ Preliminary version of the manuscript

Table 2 Experimental design used to characterize the expression of plant resistance in response to varying densities (experiment a) and timing of aphid preinfestation (experiments b, c and d). Each experiment included control plants that were not preinfested

\begin{tabular}{|c|c|c|c|c|}
\hline \multirow[t]{2}{*}{ Experiment } & \multirow{2}{*}{$\begin{array}{l}\text { Number of } \\
\text { inducing } \\
\text { aphids }\end{array}$} & \multicolumn{3}{|c|}{$\begin{array}{l}\text { Total time from beginning of feeding by inducing aphids to } \\
\text { testing for induced resistance (h) }[1]+[2]\end{array}$} \\
\hline & & $\begin{array}{l}\text { Duration of } \\
\text { feeding [1] }\end{array}$ & $\begin{array}{l}\text { Time between the end of } \\
\text { feeding and testing for } \\
\text { induced resistance [2] }\end{array}$ & {$[1]+[2]$} \\
\hline \multirow[t]{4}{*}{$\mathrm{a}(n=10)$} & 1 & 48 & 0 & 48 \\
\hline & 5 & 48 & 0 & 48 \\
\hline & 10 & 48 & 0 & 48 \\
\hline & 20 & 48 & 0 & 48 \\
\hline \multirow[t]{4}{*}{$\mathrm{b}(n=6)$} & 20 & 6 & 0 & 6 \\
\hline & 20 & 12 & 0 & 12 \\
\hline & 20 & 24 & 0 & 24 \\
\hline & 20 & 48 & 0 & 48 \\
\hline \multirow[t]{3}{*}{ c $(n=9$ to 10$)$} & 20 & 3 & 45 & 48 \\
\hline & 20 & 6 & 42 & 48 \\
\hline & 20 & 9 & 39 & 48 \\
\hline \multirow[t]{3}{*}{$\mathrm{d}(n=10)$} & 20 & 48 & 0 & 0 \\
\hline & 20 & 48 & 24 & 72 \\
\hline & 20 & 48 & 48 & 96 \\
\hline
\end{tabular}

$n$ represents the number of plant replicates, with 10 aphids per plant 
Version préliminaire du manuscrit/ Preliminary version of the manuscript

Table 3 Effect of aphid density (experiment a) and timing of preinfestation (experiments b, c and d) on the plant-leaving tendency of Myzus persicae

\begin{tabular}{|c|c|c|c|c|c|c|c|c|}
\hline Experiment & Covariates & $\beta$ & $\mathrm{SE}(\beta)$ & $\exp (\beta)$ & $n$ & $\chi^{2}$ (d.f.) & $P$ & $\begin{array}{l}\text { Effect on } \\
\text { leaving } \\
\text { tendency }\end{array}$ \\
\hline \multirow[t]{5}{*}{$\mathrm{a}$} & Treatment effect & & & & 500 & $135(4)$ & $<0.0001$ & \\
\hline & -1 aphid & 1.84 & 0.210 & $6.31^{* * *}$ & & & & + \\
\hline & -5 aphids & 1.71 & 0.206 & $5.53^{* * *}$ & & & & + \\
\hline & -10 aphids & 1.78 & 0.208 & $5.95^{* * *}$ & & & & + \\
\hline & -20 aphids & 1.57 & 0.206 & $4.80^{* * *}$ & & & & + \\
\hline \multirow[t]{5}{*}{ b } & Treatment effect & & & & 300 & $37.2(4)$ & $<0.0001$ & \\
\hline & $-6 \mathrm{~h}$ & 0.339 & 0.218 & 0.71 & & & & no effect \\
\hline & $-12 \mathrm{~h}$ & 0.322 & 0.211 & 1.38 & & & & no effect \\
\hline & $-24 \mathrm{~h}$ & 0.267 & 0.215 & 1.31 & & & & no effect \\
\hline & $-48 \mathrm{~h}$ & 0.911 & 0.207 & $2.45^{* * *}$ & & & & + \\
\hline \multirow[t]{4}{*}{ c } & Treatment effect & & & & 390 & $24.3(3)$ & $<0.0001$ & \\
\hline & $-3 h+45 h$ & 0.432 & 0.164 & $1.54^{* *}$ & & & & + \\
\hline & $-6 h+42 h$ & 0.610 & 0.164 & $1.84^{* * *}$ & & & & + \\
\hline & $-9 h+39 h$ & 0.726 & 0.162 & $2.07^{* * *}$ & & & & + \\
\hline \multirow[t]{4}{*}{$d$} & Treatment effect & & & & 400 & 71.9 (3) & $<0.0001$ & \\
\hline & $-48 \mathrm{~h}$ & 1.427 & 0.201 & $4.17^{* * *}$ & & & & + \\
\hline & $-48 h+24 h$ & 1.228 & 0.205 & $3.41^{* * *}$ & & & & + \\
\hline & $-48 h+48 h$ & 0.494 & 0.209 & $1.64^{*}$ & & & & + \\
\hline
\end{tabular}

Estimated regression coefficients $(\beta)$, standard errors (SE) and hazard ratios [exp ( $\beta$ )] for the covariates of a Cox proportional hazards model. $\chi^{2}$ correspond to a likelihood ratio test. *, **, ***, levels of significance as compared to the baseline hazard (uninfested control) for the coefficients at $P<0.05,0.01$ and 0.001 respectively. + indicates an increasing effect of the covariate on the plant-leaving tendency. The more remote the hazard ratio to zero, the stronger the plant-leaving tendency 
Version préliminaire du manuscrit/ Preliminary version of the manuscript

Table 4 Effect of the genotype of Myzus persicae on the plant-leaving tendency as estimated by a Cox proportional hazards model $\left(n=1550, \chi^{2}\right.$ $=167$, d.f. $=30, P<0.0001)$

\begin{tabular}{lllll}
\hline Covariates & $\beta$ & SE $(\beta)$ & exp $(\beta)$ & $\begin{array}{l}\text { Effect on } \\
\text { leaving } \\
\text { tendency }\end{array}$ \\
\hline -Mp03 & -0.692 & 0.205 & $0.500 * * *$ & - \\
-Car 16 & -0.094 & 0.202 & 0.909 & no effect \\
-Car 8 & -0.086 & 0.203 & 0.917 & no effect \\
-Car 14 & -0.077 & 0.200 & 0.926 & no effect \\
-Car 6 & -0.053 & 0.202 & 0.948 & no effect \\
-Avi 5 & -0.028 & 0.200 & 0.972 & no effect \\
-Car 11 & -0.003 & 0.201 & 0.996 & no effect \\
-Car 3 & 0.008 & 0.201 & 1.009 & no effect \\
-Car 15 & 0.043 & 0.204 & 1.044 & no effect \\
-Car 2 & 0.047 & 0.201 & 1.048 & no effect \\
-Got 7 & 0.122 & 0.201 & 1.131 & no effect \\
-Car 4 & 0.149 & 0.200 & 1.161 & no effect \\
-Avi 3 & 0.189 & 0.201 & 1.208 & no effect \\
-Avi 2 & 0.197 & 0.200 & 1.218 & no effect \\
-Avi 6 & 0.208 & 0.201 & 1.232 & no effect \\
-Got 4 & 0.228 & 0.209 & 1.257 & no effect \\
-Got 5 & 0.242 & 0.201 & 1.275 & no effect \\
-Got 2 & 0.288 & 0.200 & 1.334 & no effect \\
-Car 10 & 0.288 & 0.200 & 1.334 & no effect \\
-Got 8 & 0.296 & 0.200 & 1.345 & no effect \\
-Avi 1 & 0.307 & 0.201 & 1.360 & no effect \\
-Car 5 & 0.365 & 0.200 & 1.442 & no effect \\
-Got 3 & 0.375 & 0.201 & 1.456 & no effect \\
-Got 6 & 0.388 & 0.201 & 1.475 & no effect \\
-Car 9 & 0.419 & 0.201 & $1.521 *$ & + \\
-Car 12 & 0.509 & 0.201 & $1.664 *$ & + \\
-Car 7 & 0.639 & 0.201 & $1.895 * *$ & + \\
-Car 13 & 0.750 & 0.201 & $2.119 * * *$ & + \\
-Avi 4 & 0.942 & 0.202 & $2.567 * * *$ & + \\
-Car 1 & 1.302 & 0.202 & $3.679 * * *$ & + \\
\hline
\end{tabular}

Estimated regression coefficients ( $\beta$ ), standard errors (SE) and hazard ratios $[\exp (\beta)]$ for the covariates of the model. $\chi^{2}$ correspond to a likelihood ratio test. *, **, ***, levels of significance as compared to the baseline hazard (clone Got 1 ) for the coefficients at $P<0.05,0.01$ 
Version préliminaire du manuscrit/ Preliminary version of the manuscript

and 0.001 respectively. + indicates an increasing effect; - indicates a

decreasing effect of the covariate on the plant-leaving tendency 